\title{
THE SEPARATENESS OF PERSONS: A MORAL BASIS FOR A PUBLIC JUSTIFICATION REQUIREMENT
}

\author{
JASON TYNDAL
}

\begin{abstract}
In morally grounding a public justification requirement, public reason liberals frequently invoke the idea that persons should be construed as "free and equal." But this tells us little with regard to what it is about us that makes us free or how a claim about our status as persons can ultimately ground a requirement of public justification. In light of this worry, I argue that a public justification requirement can be grounded in a Nozick-inspired argument from the separateness of persons (one that is consistent with the idea that individuals are free and equal). As I claim, one particular feature of the fact of our separateness - the possession of a basic psychology consisting of beliefs, intentions, sentiments, and a variety of desire-like psychological states - does the most work in grounding both a principle of liberty (PL) and a requirement of public justification (RPJ). Together, PL and RPJ provide the basic framework for a theory of public reason liberalism.
\end{abstract}

In locating a possible moral basis for a requirement of public justification, public reason liberals frequently invoke the idea that persons should be construed as free and equal. ${ }^{1}$ On such a conception, individuals are said to be free insofar as we are not naturally subject to the authority of others; and we are equal to one another with regard to our free status (Quong 2013; Gaus 2007, p. 90). But this tells us little with respect to what it is about us that makes us free. Consequently, it remains unclear how a general claim about our status as free and equal persons acquires the normative punch needed to underwrite a requirement of public justification.

Perhaps one plausible way to normatively prop up the claim that individuals are free and equal is to appeal to our separateness as individuals. After all, it is a fact of life that individuals are metaphysically distinct from one another. This fact has a weighty influence on how many of us view our place in the world. We conceive of ourselves as having our own life to live and, typically, we care deeply about how that life goes. We want to be free to pursue our own conception of the good life and to revise that conception as we see fit. Understandably, then, we are not usually eager to ignore or transcend our metaphysical separateness from others.

\footnotetext{
${ }^{1}$ See, for example, Rawls 1996, Boettcher 2007, Gaus 2011, Quong 2011, and Vallier 2014.
} 
One problem with such an appeal is that while the fact of our separateness may be apparent, it is less clear how it should inform our interactions with other individuals - each of whom presumably cares deeply about how his or her life goes. While moral and political theorists overwhelmingly affirm this fact (often referring to the "separateness of persons"), there is disagreement about whether the recognition of this descriptive fact implicates any normative ethico-political principles. Some theorists (Parfit 1984, McKerlie 1988, Flanagan 1991, Brink 1993) are skeptical that the descriptive fact implicates any such principles. Others (Nagel 1970, Rawls 1971, Nozick 1974, Williams 1981) think the descriptive fact at least favors, if not logically necessitates, certain normative principles (and may also disfavor certain normative principles). ${ }^{2}$

A further difficulty is that arguments from the separateness of persons - i.e., arguments that attempt to link the descriptive (metaphysical) fact of our separateness with some normative principle - tend to be underdeveloped. They generally move too quickly from the recognition of the fact of our separateness to an endorsement of one or more principles which ostensibly respect that fact. This has prompted Brian Barry, in commenting on Rawls' original position, to remark that the "import of this phrase [separateness of persons] is obscure" (Barry 1989, p. 335).

Likewise, James Griffin, in commenting on Nozick's account of rights, proclaims that we need a "further explanation of the idea of the separateness of persons" (Griffin 2008, p. 22).

Among those who appeal to the fact of our separateness, Nozick is among the few who have sought to situate the notion in a fully-developed argument from the separateness of persons. Yet, as the above remark by Griffin suggests, even Nozick's argument is at some points rushed. In light of this, I will present a revised argument from the separateness of persons. My aim is to

\footnotetext{
2 At least a few call the fact of our separateness the most basic fact of morality. See Findlay 1961, pp. 235-236; Nussbaum 1999, p. 62; and Williams 1985, p. 88.
} 
situate the fact of our separateness in an argument from the separateness of persons as a means to motivating the adoption of a public justification requirement and, more broadly, explicating the normative foundations of public reason liberalism. As I shall argue, one particular feature of the fact of our separateness - the possession of a basic psychology consisting of beliefs, intentions, sentiments, and a variety of desire-like psychological states - does the most work in grounding a principle of liberty and, when paired with some important Rawlsian insights regarding the fact of reasonable pluralism, also motivates the adoption of a requirement of public justification.

It must be acknowledged that some public reason liberals will consider such a project misguided from the outset. A constructivist will likely complain: "all of this merely assumes that a deeper normative foundation is needed. But for public reason liberals like Rawls, the aim was to avoid any such deep foundation." Three points are in order. First, the idea that individuals are "free and equal" does a great deal of theoretical work for public reason liberals, not the least of which is motivating the adoption of a public justification requirement. As such, a thorough articulation of this phrase is required if it is to do the work it is often expected to do. Second, no comprehensive moral theory will be appealed to. While I do make some metaphysical and normative suppositions, I take those suppositions to be about as uncontroversial as such suppositions can be. ${ }^{3}$ Third, I worry that public reason liberals frequently fail to appreciate that some such suppositions are already in place, even if those suppositions have not been explicitly identified. It is from this standpoint that Charles Larmore (1999) has criticized the Rawlsian project.

I will begin in $\S 1$ by briefly recounting Nozick’s argument from the separateness of persons. While Nozick identifies some key elements needed to construct a plausible argument

\footnotetext{
${ }^{3}$ As I understand it, it is the controversial metaphysical and normative suppositions that are objectionable to political constructivists.
} 
from the separateness of persons, the structure of his argument raises issues that are avoidable. In light of this, in $\S 2$, I build on important aspects of Nozick’s view in constructing a refined version of his argument. In doing so, I explain how the argument from the separateness of persons supports a principle of liberty. In $\S 3$, I discuss how Rawls, who also stresses the importance of taking seriously the fact of our separateness, fails to respect that fact in the appropriate way. Finally, in $\S 4$, I claim that the argument from the separateness of persons also helps to normatively ground a requirement of public justification insofar as it helps to motivate the adoption of a particular form of justification - justification-to. The requirement of public justification and the aforementioned principle of liberty jointly constitute the basic framework for a theory of public reason liberalism. ${ }^{4}$

$1 \quad$ Nozick's Argument from the Separateness of Persons

Nozick invokes the fact of our separateness when he writes that

[t] here are only individual people, different individual people, with their own individual lives. Using one of these people for the benefit of others, uses him and benefits the others. Nothing more... To use a person in this way does not sufficiently respect and take account of the fact that he is a separate person, that his is the only life he has. (Nozick 1974, p. 33)

Nozick appeals here to the metaphysical fact of our separateness in support of the normative claim that individuals should not be used "for the benefit of others." This normative claim is framed in terms of the "Kantian principle that individuals are ends and not merely means..." (Nozick 1974, p. 31) However, Nozick's move from the descriptive to the normative is underdeveloped. Initially, he appears to argue that recognition of the descriptive fact alone is sufficient to ground the normative principle. This is confirmed when he restates the argument:

\footnotetext{
${ }^{4}$ It is worth noting that since all contemporary liberals (broadly construed) will arguably endorse some version of a liberty principle, it is the endorsement of a public justification principle that most demarcates public reason liberals from their liberal counterparts.
} 
"there are individuals with separate lives and so no one may be sacrificed for others..." (Nozick 1974, p. 33, emphasis added) For Nozick, this inference serves as the "root idea" that grounds "the existence of moral side constraints" — constraints that prohibit us from treating others in specified ways (Nozick 1974, pp. 32-33). In Nozick's case, moral side constraints prohibit us from treating others as a mere means to our own ends or to the ends of others. But he needs an explanation for why the fact of our separateness ought to rule out treating others as a mere means. Otherwise, the inference falls short as a ground for moral side constraints.

Though Nozick's argument is a bit disjointed, he does provide us with the resources to further develop his argument from the separateness of persons. In seeking to locate one or more characteristics of persons on which to ground moral side constraints, Nozick observes that one relevant characteristic of persons is the capacity to conceive of a life plan and to "regulate and guide" one's life in light of that plan (Nozick 1974, p.49). But why not interfere with another as they shape their own life? According to Nozick,

the answer is connected with that elusive and difficult notion: the meaning of life. A person's shaping his life in accordance with some overall plan is his way of giving meaning to his life; only a being with the capacity to so shape his life can have or strive for [a] meaningful life. (Nozick 1974, p. 50) ${ }^{5}$

It is apparent from the passage in question that Nozick is concerned with the capacity of a person to shape his or her own life. Having such a capacity is valuable insofar as it enables one to strive for meaning in life. What is important, then, is that Nozick is implicitly banking on the idea that readers will place significant value on having the capacity to strive for a meaningful life. In other words, he is introducing a value claim into his argument from the separateness of persons. If readers affirm this value, then Nozick is positioned to assert that respecting this value

\footnotetext{
${ }^{5}$ Nozick speaks of meaning of life, but insofar as this notion is related to individuals shaping their own lives, I speak of meaning in life. The two notions are distinct in that the latter can exist without the former.
} 
requires preserving one's capacity to shape one's own life.

Two problems afflict Nozick's argument from the separateness of persons. First, Nozick worried that he needed to explain why one's life should not be meaningless $(1974$, p. 51$) .{ }^{6}$ This is not necessary, for we must avoid running together two distinct claims: the claim that it is a descriptive fact that we value being able to strive for a meaningful life and the claim that we should strive for a meaningful life. Nothing about the argument from the separateness of persons below requires acknowledging or defending the second (normative) claim in order to advance the Kantian principle that we should not treat others as mere means. The second problem with Nozick's argument is that it does not adequately explain how meaningfulness in one's life is grounded in one's separateness. If any argument from the separateness of persons is going to succeed, it must clearly detail what the fact of our separateness has to do with being able to lead a meaningful life. In light of this incompleteness, I will offer an argument from the separateness of persons which mirrors the framework provided by Nozick, but which seeks to fill in the gaps.

It is a fact that individuals are metaphysically distinct from one another. One feature of the fact of our separateness is that we each have, among other things, our own beliefs, intentions, sentiments, and a variety of desire-like psychological states. That is, we each possess a basic

\footnotetext{
${ }^{6}$ This was a result of Nozick claiming that an appeal to the value we place on having the capacity to lead a meaningful life "bridges" the descriptive fact of our separateness with the normative claim that one should not treat others as mere means. But Nozick does not view the bridging notion as merely a bridging notion. As he remarks, "[t]his notion... has the right 'feel' as something that might help to bridge an 'is-ought' gap; it appropriately seems to straddle the two" (Nozick 1974, p. 50, emphasis added). This, however, is problematic since it presses Nozick to worry that we might "need to answer the further question: 'But why shouldn't my life be meaningless?" (Nozick 1974, p. 51) That is, why should one strive for meaning in life? That this question is raised at all shows that Nozick views the value we place on having the capacity to lead a meaningful life not as a mere bridging notion, but as an element of the "ought" portion of the is-ought gap.
} 
psychology. ${ }^{7}$ We refer to the various features of our psychology in deciding how to act and in setting commitments as well as both short-term and long-term goals. ${ }^{8}$ It is our capacity to act in ways that are expressions of our psychology that enables us to direct our own lives — to conceive of and pursue our own conception of a meaningful life. ${ }^{9}$ This is the capacity that grounds the commonplace expression that we each have our own life to live. Thus, if one's capacity to pursue a personally meaningful life is of eminent importance, then there ought to be a presumption against interfering with that capacity. One interferes with that capacity when one coerces.

I take a coercive act to be any deliberate act which forces another individual, either physically or by the threat of future harm, to act in a way in which that individual would not have otherwise acted. ${ }^{10}$ More specifically, it is to force an individual to alienate her actions from her psychology when, absent the threat of harm, she would not have so acted. ${ }^{11}$ It is in this way that coercion is an obstruction of agency. But to override one's psychology in this way is a barefaced

\footnotetext{
${ }^{7}$ I employ the term "psychology" in a rather narrow sense as opposed to referring to the sum total of mental states and mental processes.

${ }^{8}$ This is what makes practical deliberation, in the words of Bernard Williams, "in every case first-personal, and the first person is not derivative or naturally replaced by anyone" (Williams 1985, p. 68).

${ }^{9}$ At the very least, having the ability to give personal meaning to one's life is a necessary condition of leading a meaningful (fulfilling) life. Any account of meaningfulness in life that ignores the value of personal meaning (in judging whether a life is meaningful or not) must confront the question "meaningful for whom?" For if the notion of meaningfulness in life does not have at least some subjective basis, then the claim that meaningfulness in life is deeply important to individual persons loses its force. In saying that personal meaning is only necessary, I leave open the possibility that a condition of objective worth might be necessary as well. For a recent account of meaningfulness that incorporates both subjective and objective aspects, see Wolf (2010).

${ }^{10}$ To say that coercion forces an individual to act involuntarily is not quite right. One might voluntarily act some way under the threat of force or harm. But it will still be the case that the person would have acted otherwise in the absence of the threat.

${ }^{11}$ Individuals may self-alienate insofar as their actions are not genuine expressions of their psychology. Here I am only concerned with alienation that has a source external to the individual.
} 
move to make oneself, at the very least, part author (co-author!) of the action of another. ${ }^{12}$ The problem, then, with treating others in such a way is that it amounts to claiming authority over them. ${ }^{13}$ That is, an instance of A coercing B is an instance of A claiming authority over B. To be sure, the capacity to strive for a meaningful life is unjustly interfered with even if one is forced to act in a way that is an appropriate expression of some aspect of his or her psychology. Individuals must be left to act in ways that express their psychology in the way that they choose for it to be expressed. Construed as such, the prohibition against treating others as a mere means can be framed as a principle of liberty (PL): Individuals are free to act in ways of their own choosing to the extent that their actions do not treat others as a mere means. ${ }^{14}$

A problem arises here. When exactly is one guilty of treating another as a mere means? ${ }^{15}$

Do I treat another as a mere means if I lock him in my basement against his will? What if I simply deceive another? What if I take under my control some extrapersonal object that was previously under another's control? Some clarity on these issues is needed; otherwise, the Kantian idea of not treating others as mere means might be [mis]interpreted as creating a barrier around individual lives that is never to be breached.

\footnotetext{
${ }^{12}$ Cf. Gaus (2009, p. 89).

${ }^{13}$ In the words of Isaiah Berlin, to decide how another will act is "to treat them without wills of their own" (2002, p. 184). For Berlin, when I treat others in such a way I act as if their chosen ends are (for them) "less ultimate and sacred" than my chosen ends are for me (2002, p. 184).

${ }^{14}$ Similar principles have been endorsed by others. For example, see Benn 1988, p. 87; Gaus 1996, p. 165 and 1999, pp. 118-119.

${ }^{15}$ Kant believed that we treat others as mere means when we fail to respect them as autonomous and rational individuals (1997, p. 38; $G$ 4:430). Kant's focus on autonomy and rationality helps to explain the intuition that it cannot simply be the fact of mere separateness that motivates his principle (for, if that were the case, Kant would have intended his principle to be extended to non-human animals). Rather, what is most important for Kant is the distinctively human capacity to identify ends, formulate life plans, and then to utilize our reasoning capacities to determine not just how to best pursue our personal goals and projects, but to do so in a morally acceptable way i.e., in a way that respects others as autonomous and rational beings. For Kant, these are the features of human beings that give the notion of separateness its normative force. One interpretive challenge consists in determining the conditions in which one is guilty of failing to respect another as an autonomous and rational individual. I thank an anonymous referee for pressing for clarity on this matter.
} 
I believe, first, that the argument from the separateness of persons outlined here will ground a natural ${ }^{16}$ right of self-ownership. ${ }^{17}$ To coerce an individual by threatening or harming one's person is an obstruction of agency. ${ }^{18}$ I cannot direct my own life if I cannot act in ways that are expressions of my own basic psychology, and I will not be able to act in ways that are expressions of my own basic psychology if I am not in control of my person. In other words, being at liberty to use one's own person as one sees fit is a necessary condition of being able to direct one's own life. Of course, this liberty is a liberty compatible with the equal liberty of others. Just as it would be morally wrong for you to lock me in your basement against my will, it would also be morally wrong for me to lock you in my basement against your will. As such, some constraints are placed on how each of us might go about pursuing our personal ends. ${ }^{19}$

Second, I believe there are good grounds to construe a right not to be coerced as entailing a natural right of property, understood merely as the right not to be excluded from acquiring and

\footnotetext{
${ }^{16}$ It is important not to read too much into this label. I understand the right to be natural since it is non-conventional, non-contractual, and is grounded in a feature of human life, namely in the capacity to strive for a meaningful life (Steiner 1977). As Eric Mack construes the notion, to say that individuals possesses a natural right is "not to say that persons are protected by some strange metaphysical shell. Rather, it is to assert that certain fundamental facts about each person provide reasons for others to be circumspect in their treatment of that person, for example, reasons to avoid treating that person as material which exists for their own use and purposes (Mack 2009, p. 4)." Mack's point regarding natural rights and metaphysical commitments (or the lack thereof) echoes Ronald Dworkin's claim that "the assumption of natural rights is not a metaphysically ambitious one" (1977, pp. 176-177).

${ }^{17}$ There is extensive debate over what precisely the notion of self-ownership consists of (see, for example, McElwee 2010; Sobel 2012 and 2013; Vallentyne and van der Vossen 2014). A right of self-ownership is not a single right, but rather a set of rights that demarcate some moral space with respect to one's person. Libertarians have been challenged (Sobel 2012) to articulate a conception of self-ownership that is robust enough to protect basic rights and liberties while not endorsing a notion of self-ownership that it so stringent that it generates a host of counterintuitive results. I will not take a stand here on which particular conception of self-ownership is ideal. I shall assume, however, that a right of self-ownership, at the very least, consists of a "very stringent right of control over and use of one's mind and body that bars others from intentionally using one as a means by forcing one to sacrifice life, limb, or labour" (Otsuka 2003, p. 15).

${ }^{18}$ Gerald Gaus remarks that “[c]oercion against one's natural person is a quintessential instance of interference with agency" (2011, p. 352).

${ }^{19}$ Some very minimal restraints are also placed on what ends one can pursue. If Max's chosen end is to see how many people he can lock up in his basement against their will, then Max will be prohibited from pursuing that end given that it entails treating others as mere means.
} 
exercising control over extrapersonal objects (Mack 2010, p. 54). While I will not rehearse the full details of the argument here, Eric Mack argues that if a natural right of property is not affirmed, then individuals will have little meaningful control when it comes to directing their own lives in pursuit of their own personal good given that "almost all human life, almost all human goal-pursuit, takes place in and through the purposive acquisition, transformation, and utilization of objects in the extrapersonal world" (Mack 2010, p. 62). In other words, if a natural right of property is not affirmed, the domain of instances in which an individual can act in ways that are expressions of his or her basic psychology (and do so with an expectation of noninterference) will be severely constrained - so constrained that one might wonder whether adversaries of a natural right of property take seriously the idea that individuals should be allowed to pursue their own ends as they see fit. Importantly, a natural right of property does not encompass any rights to particular extrapersonal objects - that is, it does not entail any acquired property rights. ${ }^{20}$

Despite the fact that a natural right of property assists human beings in achieving personal goals that require the utilization of extrapersonal objects, a critic might retort that even if a natural right of property greatly facilitates the satisficing of personal ends requiring the utilization of extrapersonal property, such a right does not descend from the argument from the separateness of persons with the same normative urgency that a natural right of self-ownership does. The critic might press as follows: "if there is no natural right of self-ownership, then from a

\footnotetext{
${ }^{20}$ It is plausible that some very small set of acquired property rights could be grounded in an argument from the separateness of persons. One might, for example, argue that property rights which are the result of Lockean labor mixing are solely grounded in a natural right of self-ownership and, hence, follow from the argument from the separateness of persons. I do not deny this possibility. However, the problem with Locke's labor-mixing argument is that it is not going to generate much in the way of acquired property rights in the contemporary world. So the recognition of this type of rights-generating action is not going to significantly increase the set of acquired property rights. Acquired property rights, for the public reason liberal, will mostly stem from rights-generating practices that must be publicly justified. See Mack's helpful distinction between inherent-feature conceptions and practice conceptions of property rights (2010, pp. 54-55).
} 
moral standpoint, human beings are far less distinguishable from the various inanimate objects of the world. Without a natural right of self-ownership, one may be abducted and forced into servitude and this would not be immoral unless contingent norms dictate against such practices. A world without a natural right of self-ownership is a world in which trees, rocks, and people are naturally subject to utilization by the quickest, the strongest, and the most clever amongst us. If you miss out on such genetic fortunes, and if there is no natural right of self-ownership, then the fact that you have a distinctive basic psychology - your own preferences, desires, goals, etc. does little to distinguish you, in terms of how you can be treated by others, from any old branch on the ground. In short, even if we debate about the precise nature of a natural right of selfownership, it is as close to an absurdity (if there can be one) to deny the existence of such a right."

Our critic continues: "but what if there is no natural right of property? It is no doubt correct to say that such a right expands the domain of possibilities as we think about how we want to live our lives. But it appears that the existence of such a right can be rejected with far less absurdity than the existence of a natural right of self-ownership. The denial of a natural right of property does not entail the failure to morally distinguish between human beings and branches. Nor does it necessarily contravene a principle of liberty that plausibly follows from an argument from the separateness of persons. So, a natural right of property is not as strongly and decisively supported as a natural right of self-ownership."

Those who are tempted to affirm a natural right of self-ownership while rejecting a natural right of property will want to know why we should take this alleged natural right of property as seriously as a natural right of self-ownership. Mack's answer is that if one concedes that individuals should "be allowed to pursue their own good in their own way," then one ought 
to endorse a natural right of property given that "acquiring and exercising discretionary control over extrapersonal objects is at least close to essential to agents' pursuing their own good in their own way" (Mack 2010, p. 54, emphasis added).

Let us review. The right not to be coerced - not to be treated as a mere means - entails a prohibition on threats and the use of force against one's person as well as a prohibition on excluding others from acquiring and exercising discretionary control over extrapersonal objects. PL expresses for each individual a negative right of liberty. This right should be understood as a Hohfeldian claim-right. Each individual $\mathrm{P}$ has a claim against all others which prohibits coercively infringing upon P's exercise of action $\alpha$ so long as $\alpha$ does not entail treating another as a mere means. All others have a correlative duty not to perform actions which violate PL with respect to $\mathrm{P}$.

PL allows for the possibility that coercive acts can be deemed permissible under the right conditions, whether they originate from individuals or governing bodies. As such, the argument does not entail the claim that the prohibition on treating others as a mere means is an absolute prohibition. To claim this much would be to take a Nozickean line. ${ }^{21}$ In Nozick's words, "[individuals] may not be sacrificed or used for the achieving of other ends without their consent. Individuals are inviolable" (Nozick 1974, p. 31). ${ }^{22}$ At this point, however, the argument from the

\footnotetext{
${ }^{21}$ Nozick may be willing to make an exception with regard to cases of "catastrophic moral horror" (1974, p. $30 \mathrm{fn}$.).

${ }^{22}$ If actual consent were the only permissible condition, then the acts would not be coercive (assuming the act of consent was not itself coerced). So, I am concerned with the idea that coercion can be justified even in the absence of actual consent. An important distinction is perhaps in order here. On a consent mode of justification, if a future action towards $\mathrm{P}$ has the attribute of being potentially-coercive, that action is justified only if $\mathrm{P}$ gives his or her actual consent. But all this means is that the attribute of being potentially-coercive is not realized (i.e., the act, when performed, is not in fact coercive). On such an account, there is no such thing as a legitimate coercive action since every legitimate action will be non-coercive in virtue of being consent based. One may instead, as public reason liberals typically do, appeal to a rational mode of justification in which the attribute of being potentially coercive is in fact realized, but is nevertheless legitimate if $\mathrm{P}$ has sufficient reason(s) to endorse the action (in light of a suitablydefensible account of what it means to have a reason).
} 
separateness of persons establishes only that liberty is the benchmark. ${ }^{23}$ It does not establish that the negative right of liberty as expressed by PL is an absolute right. For this reason, the right established by PL remains a right that may be overridden (i.e., justifiably infringed) under the right circumstances. ${ }^{24}$ This means that infringements of PL - i.e., coercive actions - require justification. Consequently, something must be said about the nature of justification for overriding PL. I will postpone that discussion until $§ 4$.

This argument from the separateness of persons makes no claim about why one ought to lead a meaningful life or even that one ought to lead a meaningful life. It does, however, ask us to accept that having the capacity to lead a meaningful life is something deeply important to individual persons - something taken to be worth earnestly protecting. ${ }^{25}$ As such, it is Kant's notion of not treating others as mere means that needs to be justified (not a normative claim about why one ought to lead a meaningful life). Justification for the Kantian principle is given by an appeal to the value we place on having the capacity to strive for a meaningful life, which is grounded in the ability of individuals to direct their own lives, which is in turn grounded in one feature of the fact of our separateness - that we each have our own metaphysically distinct psychology. ${ }^{26}$

\footnotetext{
${ }^{23}$ As Gaus aptly puts it, "the base condition is liberty; what needs to be argued for and agreed upon is the limitation of liberty" (Gaus 1999, p. 117).

${ }^{24}$ I follow Gewirth (1981, p. 2) with respect to some basic terminology. "A right is infringed when... the prohibited action is performed... A right is violated when it is unjustifiably infringed... [A] right is overridden when it is justifiably infringed... A right is absolute when it cannot be overridden in any circumstances."

${ }^{25}$ This does not entail the claim that societies should be politically structured to promote the actual living of meaningful lives. Respecting the capacity to strive for a meaningful life does not require promoting that capacity (Otsuka 2011, p. 50). To suggest otherwise is to make our normative principles responsive to claims about what is perceived to be "the good" rather than to an individual's moral status. To this point, the negative right of liberty expressed by PL is responsive to the moral status that we perceive individuals to already have. It does not bestow that status on individuals.

${ }^{26}$ Distinctness, of course, does not entail uniqueness.
} 
If it is true that one feature of the fact of our separateness is that each of us possesses our own psychology, and it is true that the ability to express our own psychology through action is essential to our ability to pursue a meaningful life, and, furthermore, that the ability to pursue a meaningful life is taken to be of eminent importance, then we have grounds for thinking that the fact of our separateness does have normative force. If we wish to protect the ability of individuals to pursue meaningful lives, then we must accept that respecting the fact of our separateness requires endorsing the Kantian principle (as I have construed it here). ${ }^{27}$

\section{Rawls and the Separateness of Persons}

Rawls criticizes utilitarians for failing to "take seriously the distinction between persons" (Rawls 1971, 27). While Rawls takes seriously the fact of our separateness, there are grounds for thinking that he does not take it seriously enough. The original position places contracting parties behind a veil of ignorance in which

no one knows his place in society, his class position or social status, nor does any one know his fortune in the distribution of natural assets and abilities, his intelligence, strength, and the like. I shall even assume that the parties do not know their conceptions of the good or their special psychological propensities. (Rawls 1971, 12)

Individuals behind the veil do not know what their own conception of the good is because their desires, beliefs, commitments, and so on are placed behind the veil. This is reiterated by Rawls when he says that "[n]or, again, does anyone know his conception of the good, the particulars of his rational plan of life, or even the special features of his psychology..." (Rawls

\footnotetext{
${ }^{27}$ What should we say about the person who wishes to lead a meaningful life himself, but does not care about respecting the separateness of others? Such a person evidently wants to make an exception for himself. However, since the fact of our separateness is a feature of our species, he cannot deny the separateness of others without denying his own separateness. He will have no moral grounds from which he can demand that others respect his separateness while he simultaneously fails to respect their separateness (by treating them as a mere means). His liberty must be understood as a liberty compatible with the equal liberty of all others.
} 
1971, p. 137) Consequently, the original position entails idealizing away one's ability to act on his or her own psychology. ${ }^{28}$ In other words, the original position requires the filtering out of those features that most contribute to our separateness from one another. The only feature that appears to be preserved is that we each occupy distinct spatiotemporal bodies. ${ }^{29}$ But this feature alone does not get us any obvious normative implications. As such, the problem with the original position is not merely that it dissolves differences between persons (after all, this is what models of impartial and reasonable agents tend to do), but that it dissolves differences which are crucial to giving the fact of our separateness its normative punch in the first place (in conjunction with the previously-stated value claim). Rawls then, it can plausibly be argued, does not respect the fact of our separateness in the appropriate way.

If there is any doubt that Rawls intended for knowledge of such features to be hidden behind the veil, one only needs to take note of Rawls' claim that "we can view the choice in the original position from the standpoint of one person selected at random. If anyone after due reflection prefers a conception of justice to another, then they all do, and a unanimous agreement can be reached" (Rawls 1971, 139, emphasis added). By Rawls' own admission then, each party behind the veil of ignorance adopts a strikingly similar and minimalist set of mental states and processes from which to deliberate and select political principles. The advantage of such a maneuver for the purpose of selecting political principles is that unanimity (or consensus) is vastly easier to achieve. The disadvantage is that it is difficult to see how one can be said to

\footnotetext{
${ }^{28}$ To reiterate, I am using the term "psychology" narrowly to refer to one's beliefs, intentions, sentiments, and a variety of desire-like psychological states. Individuals behind the veil of ignorance are not stripped of certain mental processes or even of knowledge of a limited set of facts pertaining to how human societies generally function (Rawls 1971, 137). But they are stripped of their knowledge of what Rawls calls the "special features" of their psychologies which includes, perhaps among other things, those features of one's psychology that I have focused on here.

${ }^{29}$ This claim entails setting aside some abnormal cases (e.g., cases of conjoined twins and dissociative identity disorder).
} 
sufficiently respect the fact of our separateness while dissolving such deep and important differences between us.

\section{$4 \quad$ Justification and the Separateness of Persons}

The argument from the separateness of persons requires that actions contrary to PL be justified. This constitutes a requirement of justification. However, it is not obvious that the argument provides us with the content of a requirement of justification. As such, more needs to be said about what justification requires. One plausible way to begin deliberating about a requirement of justification is to take note of another feature of human life. Each human being is, to borrow a phrase from Scanlon, "a locus of reasons" (1998, p. 105). That is, we are beings capable of possessing reasons, thinking about reasons, acting on reasons, and communicating those reasons (Cf. Larmore 1999, p. 607). It is because we are such beings that we are further capable of justifying ourselves to others. Of course, it is one thing to say we are capable of justifying ourselves to those that we coerce, but quite another to say that justification (with respect to coercive actions) demands this interpersonal element. To see the concern, imagine that a group of influential members of a political community is seeking to institute and enforce a coercive law that will affect a small contingent of citizens. For the law to be justified, must it be the case that the law is justified to each citizen subject to the law?

The answer is not obvious for, while the public reason liberal will reply in the affirmative, one could plausibly argue that justification simpliciter is alone sufficient to legitimize the law. Perhaps the reasoning proceeds as follows: so long as there are one or more objective, all-things-considered, reasons that normatively ground the law, advocates of the law need not worry about whether the to-be-coerced citizens do (or could) accept the reasons that 
favor implementing the law. If one member of the affected contingent, Zenith, is unable to rationally appreciate or access the justification for the law, then so be it. Her failure to be convinced by the reasoning does not serve as an impediment to the justification of the law. Let us refer to this sort of justification as impersonal justification. ${ }^{30}$

Since justification-to is a fundamental aspect of every account of public reason liberalism, it is critical that public reason liberals motivate a general preference for justificationto over impersonal justification. ${ }^{31}$ The answer starts with the need to account for the fact of reasonable pluralism. Reasonable pluralism is the condition that arises when people are permitted to "exercise the powers of human reason within an enduring background of free institutions" (Rawls 1996, p. 144). When individuals are so permitted, Rawls thought this would give rise to a "diversity of reasonable comprehensive religious, philosophical, and moral doctrines..." (1996, p. 36). What is crucial with respect to the Rawlsian insight is not simply that the exercise of human reason will lead to a wide variety of reasonable comprehensive doctrines, but that it will lead to a wide variety of reasonable disagreement when individuals, reasoning from their reasonable comprehensive doctrines, begin deliberating about the norms that should govern social and political life (Rawls 1996, p. 55ff.). Individuals reasoning about some coercive proposal $p$ from a variety of reasonable comprehensive doctrines will frequently arrive at

\footnotetext{
${ }^{30}$ A. John Simmons describes this form of justification as "the impersonal presentation of objectively good reasons or good arguments to a conclusion..." (1999, p. 762)

${ }^{31}$ While I agree with the public reason sentiment that there is a strong case for preferring justification-to (at least in the vast majority of moral and political situations involving coercion), I also think it would be a mistake to say that impersonal justification can never suffice. As I have argued, some aspects of the normative framework (namely, PL) needed to underwrite a requirement of public justification rely on impersonal justification. While this approach alienates a radical commitment to justification-to, it avoids the illiberal dissenter problem that has generally been a nuisance to public reason liberals (see Van Schoelandt (2015) for a helpful discussion of this issue). So, one consequence of my construal of the normative foundations of public reason liberalism is that justification-to is not necessary when the purpose of coercion is to stop an individual from treating another as a mere means. If a man is attempting to attack an innocent person with a knife, then the coercion of the attacker is justified (in virtue of his violation of PL) even if the attacker does not (or could not) rationally appreciate or access the reasoning for the coercion. This is further discussed below.
} 
conflicting, yet reasonable, evaluations of $p$. In such circumstances it is doubtful that we can turn to a so-called expert reasoner who, perched from a privileged epistemic position, can adjudicate such disputes impersonally. Even if this expert reasoner identifies all of the relevant reasons, he or she must evaluate those reasons and weigh them against competing reasons. But doing so often entails one or more sub-tasks: making value judgments, clarifying vague concepts, identifying any further normative considerations that aid in these tasks, and perhaps others. ${ }^{32}$ The problem is that it becomes increasingly difficult for the so-called expert reasoner(s) to distinguish between that-p and that-I-believe-that- $p .^{33}$

Accommodating the fact of reasonable pluralism, then, appears to require that, absent overriding reasons, the perspectives of those subject to a coercive proposal be treated as essential to the justification process. ${ }^{34}$ But this demands justification-to rather than impersonal justification. What Rawls recognized is that moral and political life creates a highly complex epistemic environment, one that resists the sort of objective navigation associated with impersonal justification. In light of this, when advocates of coercive laws appoint themselves as arbiters of (impersonal) justification, they are not reasoning from "up high;" rather, they are illegitimately prioritizing their own psychologies in the decision-making process and, hence,

\footnotetext{
${ }^{32}$ See Rawls' burdens of judgment (1996, pp. 56-58).

${ }^{33}$ David Enoch, in arguing against justification-to, challenges this claim (2015, p. 131)

${ }^{34}$ The practice of epistemic idealization complicates matters. To engage in epistemic idealization, with respect to reason ascriptions, is to consider what reasons a person would acknowledge for oneself if that person were deliberating under some counterfactual circumstances. For example, we might consider how Zenith would reason if she were in possession of a bit more relevant information, had more advanced reasoning skills, were without some poorly-formed beliefs, and so on. The practice of epistemic idealization complicates the issue under consideration insofar as public reason liberals who engage in the practice must balance the importance of justification-to with the need for epistemic idealization. The challenge, of course, is idealizing enough such that relatively superficial defects in reasoning do not upset the public justification of a coercive law, but not idealizing so much that there is no plausible way in which the justification of a coercive law could be understood as a justification to the actual to-becoerced citizens. Gaus (2011) develops an account of epistemic idealization that looks to answer this challenge.
} 
claiming authority over others by simply imposing their wills on them. ${ }^{35}$ Respect for persons, then, seems to demand not just a principle of liberty, but also justification-to. ${ }^{36}$

To justify an action $\alpha$ or a policy $p$ to another person is to provide that person with sufficient reasons for accepting $\alpha$ or $p$. As a result, overriding PL requires that the infringing party be able to provide sufficient reasons to the infringed if the infringement is to be justified. ${ }^{37}$ This provides us with the content of a requirement of public justification.

RPJ: An infringement of PL, i.e. a coercive action $\alpha$ (or policy $p$ ), is rationally justified if and only if each individual subject to the coercion has a sufficient reason $\mathrm{R}$ to agree to $\alpha$ (or $p) .^{38}$

RPJ is a broad and underdeveloped requirement of public justification. ${ }^{39}$ This is acceptable for my purposes here. My aim is not to lay out a fully-developed principle of public justification, but only to demonstrate how respect for the fact of our separateness plausibly leads to a requirement of public justification. This can be accomplished without specifying the precise nature of the requirement. As such, I leave open a number of questions related to particular

\footnotetext{
${ }^{35}$ We have now returned to the same concerns that motivated the adoption of a principle of liberty in $\S 2$.

${ }^{36}$ It is not uncommon for public reason liberals to argue that respect for persons demands justification-to. Larmore, for example, remarks that "to respect another person as an end is to require that coercive or political principles be as justifiable to that person as they presumably are to us" (1999, p. 608, emphasis added). Gaus and Vallier note that public reason liberalism "is based on the idea that if we are to respect others as free and equal, laws must be justified to them" (2009, p. 55). David Enoch, a critic of public reason liberalism, frames what he takes to be the standard public reason argument for justification-to as follows: "for the Pope (or any of his followers) to apply his Catholicbased directives to you non-believer as you are, will amount to giving more political weight to his (or their) beliefs than to yours, and so will amount not only to failing to treat you as free, but also to failing to treat you as an equal citizen... when we combine these two underlying intuitions, we get the slogan - the justifiability-to requirement follows from the commitment to treat each other as free and equal" (2015, p. 115).

${ }^{37}$ I am not interested in cases in which agents explicitly consent (without coercion) to be subjected to an action that would, absent uncoerced consent, treat that person as a mere means. Such cases are not in need of justification (or, one might say, are already justified).

${ }^{38}$ Cf. Gaus (2010, p. 21) and Vallier (2014, p. 24).

${ }^{39}$ It is a requirement of public justification in that if all individuals subject to a coercive policy possess (perhaps counterfactually) sufficient reasons to agree to the policy, then it is deemed reasonable from all points of view.
} 
conceptual elements of RPJ. For example, what does it means for an agent to have a reason? What counts as a sufficient reason? What types of reasons (e.g., public, non-public) can ground one's agreement to a policy? These questions are answered in different ways by different public reason liberals. So, even if there is agreement on the need for a requirement of public justification, it does not follow from this that there will necessarily be agreement about the precise demands of the requirement.

Since not all coercive actions require public justification (Wall 2010, p. 131) ${ }^{40}$ it is necessary for RPJ to reference PL. If P physically attacks Q without provocation, then forcing $\mathrm{P}$ to suspend the attack against his or her will does not require public justification. One's coercive action, as a response to $\mathrm{P}$ treating $\mathrm{Q}$ as a mere means, is justified (non-publicly) in virtue of P's infringement of PL. This is a consequence of the fact that the PL stands outside of (and is prior to) the public justificatory domain - i.e., the domain of political policies and rules of social morality which are coercive in nature, but which have passed (or need to pass) the RPJ test.

\section{$5 \quad$ Concluding Remarks}

As I have stressed, my construal of a public justification principle, RPJ, is both broad and underdeveloped. Since the conceptual elements of RPJ can be fleshed out in different ways, it follows that RPJ could be incorporated into a variety of forms of public reason liberalism. However, RPJ - specifically its relation to PL - does rule out at least one form of public reason liberalism. Because PL is external to the public justificatory domain encapsulated by RPJ, it follows that some normative content (the norm expressed by PL and the two associated natural

\footnotetext{
${ }^{40}$ While his intention is unclear, Wall may actually intend to argue the stronger point that not all coercive actions require justification simpliciter.
} 
rights) stands outside the public justificatory domain. As such, a public reason liberalism that utilizes RPJ must be committed to the claim that at least one moral norm can stand outside the domain of political policies and rules of social morality which are coercive in nature, but which have passed the RPJ test. ${ }^{41}$

\footnotetext{
${ }^{41}$ For a brief overview of why a public reason liberal might not be pleased with this, see Mack's discussion of Gaus' account of public reason liberalism (2013, pp. 400-402).
}

Acknowledgments: I would like to thank Eric Mack, Bill Glod, Gerald Gaus, and one anonymous referee for this journal for helpful comments on earlier drafts of this article. 


\section{References}

Barry, Brian. (1989). Theories of Justice. Berkeley, CA: University of California Press.

Benn, Stanley. (1988). A Theory of Freedom. New York, NY: Cambridge University Press.

Berlin, Isaiah. (2002). Liberty. Ed. Henry Hardy. New York, NY: Oxford University Press.

Boettcher, James W. (2007). "Respect, Recognition, and Public Reason." Social Theory and Practice 33, 2: 223-249.

Brink, David. (1993). "The Separateness of Persons, Distributive Norms, and Moral Theory.” In Value, Welfare, and Morality. Ed. R.G. Frey and Christopher W. Morris. New York, NY: Cambridge University Press.

Dworkin, Ronald. (1977). Taking Rights Seriously. Cambridge, MA: Harvard University Press.

Enoch, David. (2015). “Against Public Reason.” In Oxford Studies in Political Philosophy, Volume 1. Ed. David Sobel, Peter Vallentyne, and Steven Wall. New York, NY: Oxford University Press.

Findlay, John. (1961). Values and Intentions. London: George Allen \& Unwin.

Flanagan, Owen. (1991). Varieties of Moral Personality. Cambridge, MA: Harvard University Press.

Gaus, Gerald. (1996). Justificatory Liberalism. New York, NY: Oxford University Press.

— (1999). Social Philosophy. Armonk, NY: M.E. Sharpe.

- (2007). "On Justifying the Moral Rights of the Moderns: A Case of Old Wine in New Bottles." In Liberalism: Old and New. Ed. Ellen Frankel, Fred D. Miller, Jr., and Jeffrey Paul. New York, NY: Cambridge University Press.

— (2009). “The Moral Foundations of Liberal Neutrality." In Contemporary Debates in Political Philosophy. Ed. Thomas Christiano and John Christman. Malden, MA: Wiley-Blackwell.

— (2010). "The Place of Religious Belief in Public Reason Liberalism." In Multiculturalism and Moral Conflict. Ed. Maria Dimova-Cookson and Peter M.R. Stirk. New York, NY: Routledge.

— (2011). The Order of Public Reason. New York, NY: Cambridge University Press.

Gaus, Gerald and Vallier, Kevin. (2009). "The Roles of Religious Conviction in a Publicly Justified Polity." Philosophy \& Social Criticism 35, 1-2: 51-76. 
Gewirth, Alan. (1981). “Are there any Absolute Rights?” The Philosophical Quarterly 31, 122: $1-16$.

Griffin, James. (2008). On Human Rights. New York, NY: Oxford University Press.

Kant, Immanuel. (1997) [1785]. Groundwork of the Metaphysics of Morals. Ed. Mary Gregor. New York, NY: Cambridge University Press.

Larmore, Charles. (1999). “The Moral Basis of Political Liberalism.” The Journal of Philosophy 96, 12: 599-625.

Mack, Eric. (2009). John Locke. New York, NY: Continuum.

— (2010). "The Natural Right of Property." Social Philosophy and Policy 27, 1: 53-78.

— (2013). “Inside Public Reason.” Criminal Law and Philosophy 7, 2: 389-402.

McElwee, Brian. (2010). “The Appeal of Self-Ownership." Social Theory and Practice 36, 2: 213-232.

McKerlie, Dennis. (1988). "Egalitarianism and the Separateness of Persons." Canadian Journal of Philosophy 18, 2: 205-226

Nagel. Thomas. (1970). The Possibility of Altruism. Princeton, NJ: Princeton University Press.

Nozick, Robert. (1974). Anarchy, State, and Utopia. New York, NY: Basic Books.

Nussbaum, Martha. (1999). Sex and Social Justice. New York, NY: Oxford University Press.

Otsuka, Michael. (2011). “Are Deontological Constraints Irrational?” In The Cambridge Companion to Nozick's Anarchy, State, and Utopia. Ed. Ralf M. Bader and John Meadowcroft. New York, NY: Cambridge University Press.

Parfit, Derek. (1984). Reasons and Persons. New York, NY: Oxford University Press.

Quong, Jonathan. (2011). Liberalism without Perfection. New York, NY: Oxford University Press.

— (2013). "Public Reason.” The Stanford Encyclopedia of Philosophy (Summer 2013 Edition), Edward N. Zalta (ed.), URL = <http://plato.stanford.edu/archives/sum2013/entries/public-reason/>.

Rawls, John. (1971). A Theory of Justice. Cambridge, MA: Belknap Press.

— (1996). Political Liberalism. New York, NY: Columbia University Press. 
Scanlon, T.M. (1998). What We Owe to Each Other. Cambridge, MA: Belknap Press.

Simmons, A. John. (1999). “Justification and Legitimacy.” Ethics 109, 4: 739-771.

Sobel, David. (2012). "Backing Away from Libertarian Self-Ownership.” Ethics 123, 1: 32-60.

- (2013). "Self-Ownership and the Conflation Problem." In Oxford Studies in Normative Ethics: Volume 3. Ed. Mark Timmons. New York, NY: Oxford University Press.

Steiner, Hillel. (1977). "The Natural Right to the Means of Production.” The Philosophical Quarterly 27, 106: 41-49.

Vallentyne, Peter and van der Vossen, Bas. (2014). "Libertarianism.” The Stanford Encyclopedia of Philosophy (Fall 2014 Edition), Edward N. Zalta (ed.), URL = <http://plato.stanford.edu/archives/fall2014/entries/libertarianism/>.

Vallier, Kevin. (2014). Liberal Politics and Public Faith. New York, NY: Routledge.

Van Schoelandt, Chad. (2015). "Justification, Coercion, and the Place of Public Reason." Philosophical Studies 172, 4: 1031-1050.

Wall, Steven. (2010). “On Justificatory Liberalism.” Politics, Philosophy \& Economics 9, 2: 123-149.

Williams, Bernard. (1981). "Persons, Character and Morality.” In Moral Luck. New York, NY: Cambridge University Press.

— (1985). Ethics and the Limits of Philosophy. Cambridge, MA: Harvard University Press.

Wolf, Susan. (2010). Meaning in Life and Why it Matters. Princeton, NJ: Princeton University Press. 